\title{
AMINO ACID METHYL ESTERS AS AMINE COMPONENTS IN CPD-Y CATALYZED PEPTIDE SYNTHESIS: CONTROL OF SIDE REACTIONS
}

\author{
by \\ KLAUS BREDDAM, FRED WIDMER 1) \\ and \\ JACK T. JOHANSEN1) \\ Chemical Department, Carlsberg Laboratory, \\ Gamle Carlsberg Vej 10, DK-2500 Copenhagen Valby \\ 1) Present address: Carisberg Biotechnology Ltd., Tagensvej 16, DK-2200 Copenhagen N.
}

\begin{abstract}
Keyords: Carboxypeptidase Y, enzymatic peptide synthesis, phenylmercuric chloride, mercuric chloride
\end{abstract}

\begin{abstract}
Carboxypeptidase $\mathrm{Y}$ has previously been shown to catalyze the formation of peptide bonds from $\mathrm{N}$-protected amino acid methyl esters (acyl components) and amino acid methyl esters (amine components) (Carlsberg Res. Commun. 45, 453-463, 1980). However, the reaction course was difficult to control and often resulted in oligomerization. It is here demonstrated that knowledge of the kinetic constants for the CPD-Y catalyzed hydrolysis of ester substrates can be exploited in such a way that amino acid esters may be used as amine components without oligomerization. This is achieved by utilizing the fact that $\mathrm{N}$-blocked amino acid benzyl esters are much better substrates of carboxypeptidase $\mathrm{Y}$ than the corresponding methyl esters. Thus, by using $\mathrm{N}$-blocked amino acid benzyl esters as acyl components and amino acid methyl esters as amine components, peptide methyl esters are formed as the major product because they are turned over by the enzyme with a lower rate than the initial benzyl ester acyl component. It is furthermore demonstrated that carboxypeptidase $Y$ modified with phenylmercuric chloride or mercuric chloride can be used for the incorporation of amino acid methyl esters without oligomerization in cases where the unmodified enzyme yields several products.
\end{abstract}

Abbreviations: $\mathrm{Bz}=$ benzoyl; $\mathrm{Bzl}=$ benzyl $\mathrm{CPD}-\mathrm{Y}=$ carboxypeptidase $\mathrm{Y} ; \mathrm{DMF}=\mathrm{N}, \mathrm{N}$ ' dimethylformamide; Hepes $=\mathrm{N}$-2-hydroxyethylpiperazine- $\mathrm{N}$ '-2-ethanesulfonic acid; $+\mathrm{Hg}-\mathrm{CPD}-\mathrm{Y}=$ mercuric chloride inactivated $\mathrm{CPD}-\mathrm{Y} ; \mathrm{Br}-$ $\mathrm{Hg}-\mathrm{CPD}-\mathrm{Y}=+\mathrm{Hg}-\mathrm{CPD}-\mathrm{Y}$ in the presence of bromide; Ph-Hg-CPD-Y $=\mathrm{CPD}-\mathrm{Y}$ modified with phenylmercuric chloride; TEAF $=$ triethyl ammonium formate. Amino acids and derivatives are abbreviated according to the guideline of the IUPAC-IUB Commission on Biochemical nomenclature. 


\section{INTRODUCTION}

It has previously been demonstrated that $\mathrm{CPD}-\mathrm{Y}$ in the alkaline $\mathrm{pH}$ range catalyzes the formation of peptide bonds from $\mathrm{N}$-protected amino acid- or peptide esters (acyl components) and amino acids or amino acid derivatives (amine components) $(2,7,9,10)$. This feature of CPD-Y has been utilized in a step-wise synthesis of enkephalin (10) and in principle it is possible to utilize the method for the synthesis of larger peptides.

In the step-wise synthesis each elongation step consists of a coupling reaction and a conversion of the reaction product to a peptide ester which can serve as starting material in the subsequent elongation step. This reaction sequence can be achieved in three different ways using CPD-Y catalyzed reactions (Scheme 1). When amino acids are used as amine component (Method I, Reaction a) the yield of the coupling reaction

\section{Scheme 1}

The use of CPD-Y in step-wise peptide synthesis. Three different methods for synthesis of Bz-X-Y-OMe which represents the acyl component in the subsequent elongation step. The esterification reactions Ib and IIc are performed chemically. $X$ and $Y$ represents amino acid residues.

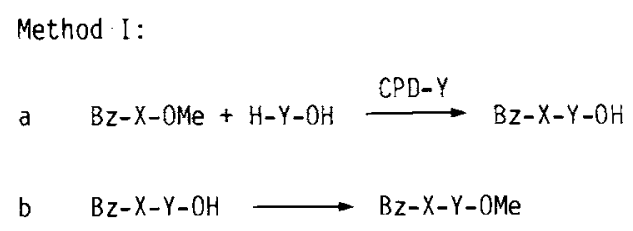

Method II :

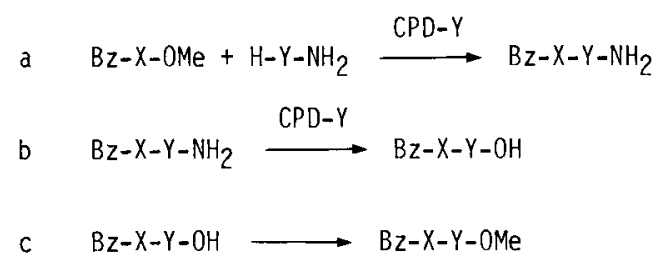

Method III:

$$
\mathrm{Bz}-\mathrm{X}-\mathrm{OMe}+\mathrm{H}-\mathrm{Y}-\mathrm{OMe} \stackrel{\mathrm{CPD}-Y}{\longrightarrow} \mathrm{Bz}-X-Y-O M e
$$

depends strongly on the particular amino acic and is rarely over $50 \%$. Amino acid amides car also be used as amine components (Method II Reaction a) and these coupling reactions are characterized by much higher yields $(7,9)$ However, the use of amino acid amides as amine components requires a subsequent deamidatior reaction (Reaction $\mathrm{IIb}$ ) which often is charac. terized by low yields because CPD-Y catalyze: both the release of ammonia (amidase activity' and the release of amino acid amides (peptidy] amino acid amide hydrolase activity) from the C-terminus of peptide amides (1). The use of amino acid esters as amine components (Meth. od III) is complicated by the fact that the initial product, a peptide ester, often reacts further in one or more additional steps. This uncontrolled oligomerization results in decreased yields of the desired product (8).

It is thus apparent that all the methods utilizing CPD-Y in the step-wise synthesis of peptides have some limitations. In the present paper it is demonstrated how an optimal selection of the size of the ester group of the acyl component results in reduced oligomerization and thus often allows the use of amino acid methyl esters as amine components.

\section{MATERIALS AND METHODS}

\subsection{Materials}

CPD-Y from baker's yeast was isolated and used for peptide synthesis as described earlier (5). L-serine methyl ester $\cdot \mathbf{H C l}$, glycine methy] ester $\cdot \mathrm{HCl}$, L-valine methyl ester $\cdot \mathbf{H C l}$, L-isoleucine methyl ester $\cdot \mathrm{HCl}$, L-leucine methyl ester $\cdot \mathrm{HCl}$, L-methionine methyl ester $\cdot \mathrm{HCl}$, Lphenylalanine methyl ester $\cdot \mathrm{HCl}$, L-histidine methyl ester $\cdot 2 \mathrm{HCl}, \mathrm{N}$-benzoyl-L-alanine methyl ester and $\mathrm{N} \alpha$-benzoyl-L-lysine methyl ester were obtained from Bachem, Switzerland. Llysine methyl ester $\cdot 2 \mathrm{HCl}$ and L-threonine methyl ester were from Vega, USA and L-alanine methyl ester $\mathrm{HCl}$ was obtained from Sigma, USA. All other reagents and solvents were from Merck, W. Germany. N-benzoyl-glycine methyl ester, N-benzoyl-glycine benzyl ester, N-benzoyl-L-alanine benzyl ester were prepared as previously described (2). CPD $Y$ was modified to yield $+\mathrm{Hg}-\mathrm{CPD}-\mathrm{Y}$ and $\mathrm{Ph}-\mathrm{Hg}-\mathrm{CPD}-\mathrm{Y}$ as previously described (3). 


\subsection{Methods}

The reactions were performed in small scale (2-5 ml) using a pH stat (7). All reactions were performed at $\mathrm{pH} 7.5$ in order to directly correlate the synthesis results with kinetic results previously determined at $\mathrm{pH} 7.5$ (3). Aliquots were taken and diluted into a ten-fold excess of acetonitrile to quench the reaction. The reactant composition was determined by HPLC using the Waters liquid chromatography system (9). Two eluant systems were used: 1) A-buffer: $10 \mathrm{~mm}$ sodium acetate, $\mathrm{pH} 4.0$, B-buffer: $80 \% \mathrm{CH}_{3} \mathrm{CN}+$ $20 \%$ A. 2) A-buffer: $50 \mathrm{~mm}$-TEAF, pH 3.5, Bbuffer: $80 \% \mathrm{CH}_{3} \mathrm{OH}+20 \% \mathrm{~A}$. All separations were carried out at room temperature and monitored at $254 \mathrm{~nm}$. The two buffer systems supplemented each other, since separations not possible in one system were possible using the other system. Aminolysis and hydrolysis products, not identifiable by chromatography of authentic samples, were collected and identified by amino acid analysis. Two peaks with identical amino acid analysis were assigned such that the peptide ester eluted later than the free acid form. The per cent composition could be calculated directly from the integrated peak areas since all products had the benzoyl group as a common chromophore.

\section{RESULTS AND DISCUSSION}

In the CPD-Y catalyzed reaction utilizing an $\mathrm{N}$-blocked amino acid methyl ester (Bz-X-OMe) as acyl component and an amino acid methyl ester (H-Y-OMe) as amine component (Method III, Scheme 1), difficulties arise since the ester product of the reaction, Bz-X-Y-OMe, may undergo further reaction steps. However, this may be prevented if the product is a poor substrate for CPD-Y relative to the initial substrate, $\mathrm{Bz}-\mathrm{X}$ OMe. The rate of hydrolysis of ester substrates of the general formula $\mathrm{Bz}-\mathrm{X}$-OMe depends strongly on the nature of the amino acid residue occupying the $\mathrm{X}$ position (3), suggesting that $\mathrm{Bz}-\mathrm{X}$ OMe in favorable cases will be a much better substrate of the enzyme than Bz-X-Y-OMe, thus allowing accumulation of the latter. In less favorable cases, subsequent elongation steps could potentially be suppressed by increasing the reactivity of the initial acyl component, relative to the product, $\mathrm{Bz}-\mathrm{X}-\mathrm{Y}-\mathrm{OMe}$. It has previously been observed that the esterase activity of CPD$Y$ increases dramatically with the size of the ester leaving group (3) essentially with no effect on the yield of synthesis (2). It thus seemed possible that use of $\mathrm{Bz}-\mathrm{X}-\mathrm{OBzl}$ in place of $\mathrm{Bz}-\mathrm{X}-\mathrm{OMe}$ as acyl component might result in accumulation of $\mathrm{Bz}$ $\mathrm{X}$-Y-OMe in higher yields, because at the low concentrations of enzyme required to convert $\mathrm{Bz}-\mathrm{X}-\mathrm{OBz}$ to $\mathrm{Bz}-\mathrm{X}-\mathrm{Y}-\mathrm{OMe}$, the latter would not undergo further reactions.

The results in Table I demonstrate the effect of the ester leaving group on the reactant composition using a series of amino acid methyl esters as amine components. The two substrates used in the reactions are $\mathrm{Bz}-\mathrm{Ala}-\mathrm{OMe}$ and $\mathrm{Bz}-\mathrm{Ala}-\mathrm{OBzl}$, and the results of the synthesis reactions with these two compounds are compared at a time of the reaction where approximately the same amount of substrate is converted (80-95\%). Since the amine component is of the general type $\mathrm{H}$ Y-OMe ( $Y=$ amino acid residue), the initial coupling product is of the type Bz-Ala-Y-OMe and the hydrolysis product is Bz-Ala-OH. Secondary reaction products formed by hydrolysis and aminolysis reactions of Bz-Ala-Y-OMe accumulated only to a minor extent when Bz-AlaOMe was used with H-Gly-OMe, H-Ser-OMe, $\mathrm{H}$-Thr-OMe, H-His-OMe and H-Lys-OMe as amine components. This suggests that Bz-AlaOMe is a sufficiently good substrate in these cases to allow accumulation of Bz-Ala-Y-OMe, consistent with the fact that Bz-Ala-OMe is a much better substrate than Bz-Gly-OMe, BzSer-OMe, Bz-Thr-OMe, Bz-His-OMe and BzLys-OMe (3). The use of Bz-Ala-OBzl instead of Bz-Ala-OMe therefore only had a small effect on the yield of Bz-X-Y-OMe. Conversely, when $\mathrm{H}$ Ile-OMe, H-Val-OMe, H-Leu-OMe, H-Met$\mathrm{OMe}$ and $\mathrm{H}$-Phe-OMe were used as amine components in reactions using Bz-Ala-OMe as acyl component, the yield of Bz-X-Y-OMe was low and significant amounts of secondary reaction products accumulated, suggesting that Bz-AlaOMe was not of sufficient reactivity in these cases to allow accumulation of Bz-Ala-Y-OMe. This is consistent with the fact that Bz-Ala-OMe is a poor substrate for CPD-Y relative to $\mathrm{Bz}$-Leu$\mathrm{OMe}, \mathrm{Bz}-\mathrm{Met}-\mathrm{OMe}$ and $\mathrm{Bz}-\mathrm{Phe}-\mathrm{OMe}$, and only a slightly better substrate than Bz-Ile-OMe and $\mathrm{Bz}$-Val-OMe (3). Performing the reactions with 
Table I,

CPD-Y catalyzed peptide synthesis using Bz-Ala-OX as acyl component and amino acid methyl esters as amine components: Effect of leaving group.

\begin{tabular}{|c|c|c|c|c|c|c|}
\hline \multirow{2}{*}{$\begin{array}{l}\text { Acyl } \\
\text { component } \\
\text { (Bz-Ala-OX) }\end{array}$} & \multirow{2}{*}{$\begin{array}{c}\text { Amine } \\
\text { component } \\
\text { (H-Y.OMe) }\end{array}$} & \multicolumn{5}{|c|}{ Products (\%) } \\
\hline & & Bz-Ala-Y-OMe & Bz-Ala-OH & Bz-Ala-Y-OH & Bz-Ala- $Y_{n>1}$ & Bz-Ala-OX \\
\hline Bz-Ala-OMe & H-Gly-OMe & 49 & 41 & 5 & 0 & 4 \\
\hline Bz-Ala-OBzl & H-Gly-OMe & 54 & 38 & 3 & 0 & 5 \\
\hline Bz-Ala-OMe & $\mathrm{H}$-Ser-OMe & 52 & 36 & 8 & 0 & 4 \\
\hline Bz-Ala-OBzl & H-Ser-OMe & 61 & 31 & 1 & 0 & 7 \\
\hline $\mathrm{Bz}$-Ala-OMe & H-Thr-OMe & 55 & 41 & 0 & 0 & 4 \\
\hline $\mathrm{Bz}-\mathrm{Ala}-\mathrm{OBzl}$ & H-Thr-OMe & 68 & 30 & 0 & 0 & 2 \\
\hline Bz-Ala-OMe & H-Val-OMe & 26 & 34 & 23 & 7 & 10 \\
\hline Bz-Ala-OBzl & H-Val-OMe & 60 & 36 & 0 & 0 & 4 \\
\hline Bz-Ala-OMe & H-Ile-OMe & 32 & 41 & 23 & 0 & 4 \\
\hline Bz-Ala-OBzl & H-Ile-OMe & 72 & 22 & 2 & 0 & 4 \\
\hline Bz-Ala-OMe & H-Leu-OMe & 3 & 50 & 13 & 31 & 3 \\
\hline Bz-Ala-OBzl & H-Leu-OMe & 22 & 26 & 18 & 29 & 5 \\
\hline Bz-Ala-OMe & H-Met-OMe & 8 & 31 & 55 & 0 & 6 \\
\hline Bz-Ala-OBzl & H-Met-OMe & 53 & 20 & 15 & 7 & 5 \\
\hline Bz-Ala-OMe & H-Phe-OMe & 2 & 52 & 40 & 0 & 6 \\
\hline Bz-Ala-OBzl & H-Phe-OMe & 48 & 7 & 15 & 10 & 20 \\
\hline Bz-Ala-OMe & $\mathrm{H}$-His-OMe & 48 & 41 & 9 & 0 & 2 \\
\hline Bz-Ala-OBzl & $\mathrm{H}$-His-OMe & 48 & 41 & 5 & 0 & 2 \\
\hline Bz-Ala-OMe & H-Lys-OMe & 26 & 70 & 2 & 0 & 2 \\
\hline Bz-Ala-OBzl & H-Lys-OMe & 29 & 65 & 2 & 0 & 4 \\
\hline
\end{tabular}

The reactions were performed at $\mathrm{pH} 7.5 \mathrm{using}$ a substrate concentration of $1.5 \mathrm{~mm}-\mathrm{Bz}-\mathrm{Ala}-\mathrm{OBzl}$ and $10 \mathrm{~mm}-\mathrm{Bz}-$ Ala-OMe. The concentration of amine component varied: $0.25 \mathrm{~m}$ for H-Leu-OMe, H-Ile-OMe, H-Met-OMe, HPhe-OMe and H-Val-OMe. For H-Lys-OMe, H-Gly-OMe and H-Ser-OMe the concentration was $3.0 \mathrm{M}$. For HThr-OMe and H-His-OMe the concentration was $2.0 \mathrm{M}$ and $2.6 \mathrm{M}$, respectively. The enzyme concentration was $0.03 \mu \mathrm{m}$ when Bz-Ala-OBzl was used as substrate and $1.5 \mu \mathrm{m}$ when Bz-Ala-OMe was used as substrate. The reaction time was $15-30$ minutes.

these nucleophiles using Bz-Ala-OBzl instead of Bz-Ala-OMe results in a significant improvement in the yield of Bz-Ala-Y-OMe, suggesting that using a larger ester leaving group in the acyl component was sufficient to render this a better substrate than Bz-Ala-Y-OMe, except when $\mathrm{Y}=$ Leu, a reaction which still is characterized by accumulation of large amounts of secondary reaction products.

The failure in synthesizing Bz-Ala-Leu-OMe in high yield using Bz-Ala-OBzl as acyl component (Table I) is an example which demonstrates that the specificity of CPD-Y towards the C-terminal amino acid residues in peptide esters lim- its the applicability of some amino acid methyl esters as amine components. However, it has been demonstrated that CPD-Y modified with phenylmercuric chloride (Ph-Hg-CPD-Y) and CPD-Y modified with $\mathrm{Hg}^{++}(+\mathrm{Hg}-\mathrm{CPD}-\mathrm{Y})$ provided it is assayed in the presence of halogen ions to form e.g. Br-Hg-CPD-Y - both exhibit a different specificity from that of the unmodified enzyme (3). The preference of Ph-Hg-CPD-Y for ester substrates with bulky C-terminal amino acid residues is much less pronounced than that observed for unmodified enzyme. This derivative of CPD-Y may therefore be more suitable for the synthesis of a peptide ester Bz-X-Y-OMe 


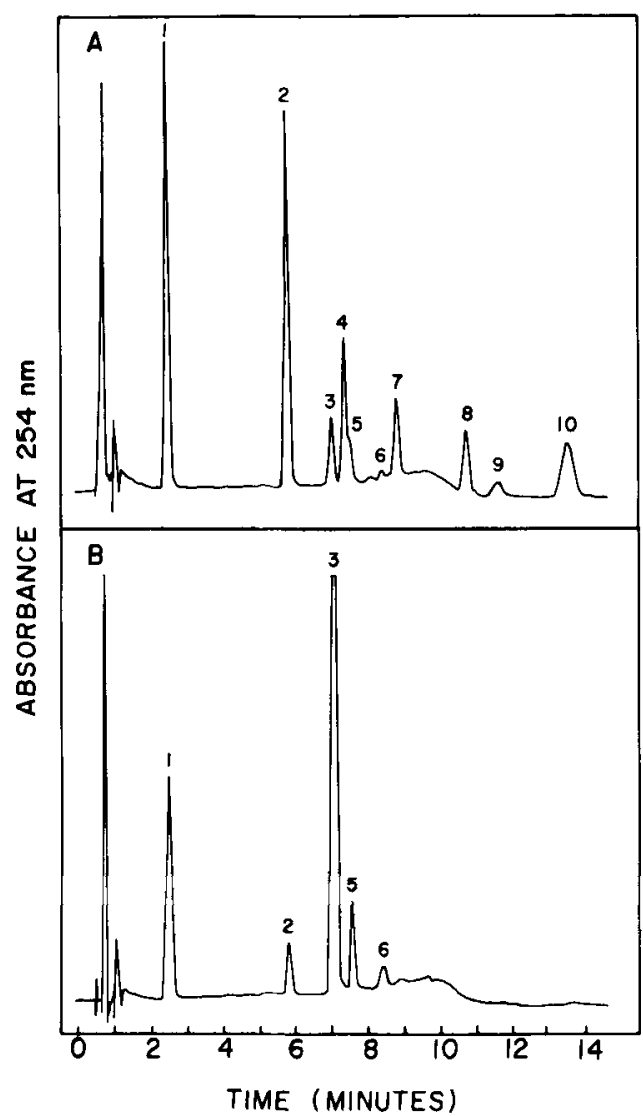

Figure 1. HPLC chromatograms of peptides formed by CPD-Y and Ph-Hg-CPD-Y catalyzed reaction of BzAla-OBzl and $\mathrm{H}$-Leu-OMe.

The reactions were performed at $\mathrm{pH} 7.5$ using 1.5 mM-Bz-Ala-OBzl and 0.25 M-H-Leu-OMe. Panel A: The reaction was performed with $0.2 \mu \mathrm{M}-\mathrm{CPD}-\mathrm{Y}$ and quenched at $6 \mathrm{~min}$. Panel $\mathrm{B}$ : The reaction was performed with $1.0 \mu \mathrm{M}-\mathrm{Ph}-\mathrm{Hg}-\mathrm{CPD}-\mathrm{Y}$ and quenched at 2 min. The following peaks were assigned: 1: Bz-Ala$\mathrm{OH}, 2$ : Bz-Ala-Leu-OH, 3: Bz-Ala-Leu-OMe, 4: BzAla-Leu-Leu-OH, 5: Bz-Ala-OBzl, 6: Bz-Ala-(Leu $)_{2}$ OMe, 7: Bz-Ala-(Leu) $)_{3}-\mathrm{OH}, 8$ : Bz-Ala-(Leu) $)_{3}$-OMe, 9 : Bz-Ala-(Leu $)_{4}-\mathrm{OH}, 10$ : Bz-Ala-(Leu $)_{4}$-OMe. HPLC conditions: A-buffer: $50 \mathrm{~mm}$-TEAF, B-buffer: $80 \%$ $\mathrm{CH}_{3} \mathrm{OH}+20 \% \mathrm{~A}$. The gradient used was: $45 \% \mathrm{~B}$ to $100 \% \mathrm{~B}$ in 8 minutes using a linear gradient and a flowrate of $4 \mathrm{ml} \cdot \mathrm{min}^{-1}$.

where $\mathrm{X}$ is a non-bulky amino acid residue and $Y$ is a bulky amino acid residue, because with this enzyme the reactivity of $\mathrm{Bz}-\mathrm{X}-\mathrm{Y}$-OMe relative to $\mathrm{Bz}-\mathrm{X}-\mathrm{OMe}(-\mathrm{OBzl})$ may be reduced. The HPLC chromatograms in Figure 1 compare the reactant composition of a CPD-Y (Panel A) and a Ph-Hg-CPD-Y (Panel B) catalyzed synthesis of Bz-Ala-Leu-OMe from Bz-Ala-OBzl and $\mathrm{H}$ Leu-OMe. It is apparent that the initial coupling product, Bz-Ala-Leu-OMe, is accumulated in higher yield when Ph-Hg-CPD-Y is used, and that products containing additional leucine residues are almost absent. The reactant composition of this and other similar reactions are summarized in Table II. In all these cases a higher yield of the desired coupling product is the consequence of using Ph-Hg-CPD-Y instead of native $C P D-Y$ in peptide synthesis with amino acid methyl esters as amine components. The effect is most pronounced when H-Leu-OMe is used as amine component since the yield of Bz-Gly-LeuOMe is increased from $3 \%$ to $67 \%$ and the yield of Bz-Ala-Leu-OMe is increased from $22 \%$ to $74 \%$.

Compared to unmodified CPD-Y, Br-HgCPD-Y exhibits a dramatically increased preference for Lys as C-terminal amino acid residue in ester substrates (3). This enzyme-derivative might therefore be better suited for the synthesis of peptides using Bz-Lys-OMe as acyl component, since any product of the type Bz-Lys-YOMe will be less reactive relative to $\mathrm{Bz}-\mathrm{L} y \mathrm{~s}-\mathrm{OMe}$ than observed for the unmodified enzyme. Thus, Bz-Lys-Y-OMe might accumulate in higher yield. Using H-Gly-OMe as amine component in this reaction, it is demonstrated that Bz-LysGly-OMe accumulates in higher yield with $\mathrm{Br}$ $\mathrm{Hg}-\mathrm{CPD}-\mathrm{Y}$ than with unmodified enzyme (Table II).

The present results indicate that amino acid methyl esters can be used as amine components in CPD-Y catalyzed peptide synthesis without significant accumulation of secondary reaction products. This is especially so if an N-protected amino acid or peptide benzyl ester is used as acyl component, or if CPD-Y is used in a suitably modified form. In many cases the yield of each elongation step will thus be higher with this method than with methods I and II in Scheme 1. For example, using as amine component the free acids of His, Ser, Val, Ile or Thr (Method I), the coupling yields were less than $50 \%$ (9). Using the amides of these amino acids as amine component (Method II), the yield of the necessary deamidation step (Reaction b) was always very low (1), and Method II is thus not particularly suita- 
Table II.

CPD-Y catalyzed peptide synthesis using N-blocked amino acid esters as acyl components and amino acid methyl esters as amine components: Effect of modification of CPD-Y with phenyl mercuric chloride and mercuric chloride.

\begin{tabular}{|c|c|c|c|c|c|c|c|}
\hline \multirow{2}{*}{$\begin{array}{l}\text { Acyl } \\
\text { component } \\
\text { (Bz-X-OZ) } \\
\end{array}$} & \multirow[b]{2}{*}{ Enzyme } & \multirow{2}{*}{$\begin{array}{l}\text { Amine } \\
\text { component } \\
\text { (H-Y-OMe) }\end{array}$} & \multicolumn{5}{|c|}{ Reactant composition (\%) } \\
\hline & & & $\mathrm{Bz}-\mathrm{X}-\mathrm{Y}-\mathrm{OMe}$ & $\mathrm{Bz}-\mathrm{X}-\mathrm{OH}$ & $\mathrm{Bz}-\mathrm{X}-\mathrm{Y}-\mathrm{OH}$ & $B z-X-Y_{n>1}$ & $\mathrm{Bz}-\mathrm{X}-\mathrm{OZ}$ \\
\hline Bz-Gly-OBzl & CPD-Ya) & H-Leu-OMe & 3 & 15 & 63 & 12 & 7 \\
\hline Bz-GlyOBzl & $\mathrm{Ph}-\mathrm{Hg}-\mathrm{CPD}-\mathrm{Yb}^{b}$ & H-Leu-OMe & 67 & 15 & 14 & 3 & 1 \\
\hline Bz-Ala-OBzl & CPD-Ya) & H-Leu-OMe & 22 & 26 & 18 & 29 & 5 \\
\hline Bz-Ala-OBzl & $\mathrm{Ph}-\mathrm{Hg}-\mathrm{CPD}-\mathrm{Yb}^{\mathrm{b}}$ & H-Leu-OMe & 74 & 17 & 3 & 1 & 5 \\
\hline Bz-Ala-OBzl & CPD-Ya) & H-Phe-OMe & 48 & 7 & 15 & 10 & 20 \\
\hline Bz-Ala-OBzl & $\mathrm{Ph}-\mathrm{Hg}-\mathrm{CPD}-\mathrm{Yb})$ & H-Phe-OMe & 59 & 17 & 6 & 0 & 18 \\
\hline Bz-Ala-OMe & CPD-Ya) & H-Ile-OMe & 32 & 41 & 23 & 0 & 4 \\
\hline Bz-Ala-OMe & $\mathrm{Ph}-\mathrm{Hg}-\mathrm{CPD}-\mathrm{Yb}^{\mathrm{b}}$ & H-Ile-OMe & 69 & 19 & 6 & 0 & 6 \\
\hline Bz-Lys-OMe & CPD-Ya) & H-Gly-OMe & 4 & 10 & 56 & 4 & 26 \\
\hline Bz-Lys-OMe & $\mathrm{Br}-\mathrm{Hg}-\mathrm{CPD}-\mathrm{Yb})$ & H-Gly-OMe & 52 & 10 & 24 & 0 & 14 \\
\hline
\end{tabular}

The reactions were performed at $\mathrm{pH} 7.5$ using $0.25 \mathrm{M}$-amine component except $\mathrm{H}$-Gly-OMe which was $1.5 \mathrm{~m}$ and $1.5 \mathrm{~mm}$-Bz-Ala-OBzl, $2.5 \mathrm{~mm}$-Bz-Gly-OBzl $5 \mathrm{~mm}-\mathrm{Bz}-\mathrm{Lys}-\mathrm{OMe}$ and $10 \mathrm{~mm}$-Bz-Ala-OMe. Enzyme concentrations: a) Bz-Ala-OBzl: $0.03 \mu \mathrm{m}$-CPD-Y, Bz-Gly-OBzl: $4.5 \mu \mathrm{m}-\mathrm{CPD}-Y$, Bz-Lys-OMe: $85 \mu \mathrm{m}$-CPD-Y, Bz-Ala-OMe: $1.5 \mu \mathrm{m}-$ CPD-Y.

b) Bz-Ala-OBzl: $0.1 \mu \mathrm{m}$-Ph-Hg-CPD-Y, Bz-Gly-OBzl: $10 \mu \mathrm{m}-\mathrm{Ph}-H g-C P D-Y$, Bz-Lys-OMe: $5.4 \mu \mathrm{m}-\mathrm{Br}-\mathrm{Hg}-\mathrm{CPD}-Y$, Bz-Ala-OMe: $5.3 \mu \mathrm{m}$-Ph-Hg-CPD-Y. The reaction time was 15-60 min.

ble for the incorporation of these amino acids. In contrast, as presented here, incorporation of these amino acids as the methyl esters (Method III) resulted in yields of $50 \%$ and higher.

The results obtained with the modified forms of CPD-Y demonstrate that if naturally occurring enzymes with the proper specificity are not available, already accessible enzymes may be "tailor-made" for specific purposes by chemical modification of binding sites resulting in desired specificity changes. Such chemical modifications need not necessarily be of a covalent nature as was shown by the enhanced tryptic hydrolysis of $\mathrm{N}$-acyl amino acid esters other than lysine and arginine in the presence of methyl- or ethylamine (4). This induced specificity change can also be exploited to widen the scope of the enzyme in peptide synthesis and was used for tryptic coupling at alanine, serine and histidine residues (11).

These two examples of deliberate specificity changes of proteases for the purpose of using them in peptide synthesis are special cases of protein engineering (6). That is, they represent successful attempts to rationally modify properties of proteins, to suit specific purposes, based on available enzymological and protein chemical information.

\section{ACKNOWLEDGEMENTS}

The authors gratfully acknowledge Professor MARTIN OTtesen for his advise at all stages of the work and for critically revising the manuscript. Ms. IREnE SimOnSEN is acknowledged for excellent technical assistance, and Ms. PIA BREDdaM for performing the drawing.

\section{REFERENCES}

1. BReddam, K., F. Widmer \& J.T. Johansen: Carboxypeptidase $Y$ catalyzed transpeptidations and enzymatic peptide synthesis. Carlsberg Res. Commun. 45, 237-247 (1980)

2. BREDdAM, K., F. Widmer \& J.T. JohanSEN: Influence of the substrate structure on carboxypeptidase $Y$ catalyzed peptide bond formation. Carlsberg Res. Commun. 45, 361-367 (1980)

3. BREDDAM, K.: Modification of the single sulfhydryl group of carboxypeptidase $\mathrm{Y}$ with mercurials. Influence on enzyme specificity. Carlsberg Res. Commun. 48, 9-19 (1983)

4. Inagami, T. \& T. Murachi: The mechanism of the specificity of trypsin catalysis. J. Biol. Chem. 239, 1395-1401 (1964)

5. Johansen, J.T., K. Breddam \& M. Ottesen: Isolation of carboxypeptidase $\mathrm{Y}$ by affinity chromatography. Carlsberg Res. Commun. 41, 1-14 (1976) 
6. Ulmer, M.K.: Protein Engineering. Science 219, 666-671 (1983)

7. WIDMER, F \& J.T. JOHANSEN: Enzymatic peptide synthesis. Carboxypeptidase $Y$ catalyzed formation of peptide bonds. Carlsberg Res. Commun. 44, 37-46 (1979)

8. Widmer, F., K. BReddam \& J.T. Johansen: Carboxypeptidase $Y$ catalyzed peptide synthesis using amino acid alkyl esters as amine components. Carlsberg Res. Commun. 45, 453-463 (1980)

9. Widmer, F., K. BREDdam \& J.T. JohanSEN: Influence of the structure of amine components carboxypeptidase $\mathrm{Y}$ catalyzed amide bond for mation. Carlsberg Res. Commun. 46, 97-106 (1981)

10. Widmer, F., K. Breddam \& J.T. Johansen: Carboxypeptidase $Y$ as a catalyst for peptide synthesis in aqueous phase with minimal protection. In: Proc. 16th European Peptide Symposium. K. Brunfeldt ed., Scriptor. Copenhagen pp. 46-55 (1981)

11. Widmer, F., M. Ohno, M. Smith, N. Nelson \& C.B. ANFINSEN: Enzymatic peptide synthesis. In: Proc. 17th European Peptide Symposium. $\mathrm{K}$. Blaha, ed., de Gruyter, Berlin, in press (1983) 